\title{
Pollution intensity-dependent metal accumulation in ground beetles: a meta-analysis
}

\author{
Dávid Tőzsér $^{1} \cdot$ Tibor Magura $^{1} \cdot$ Edina Simon ${ }^{1} \cdot$ Szabolcs Mizser $^{2} \cdot$ Dalma Papp $^{1} \cdot$ Béla Tóthmérész $^{2}$
}

Received: 15 February 2019 / Accepted: 26 August 2019 / Published online: 7 September 2019

(C) The Author(s) 2019

\begin{abstract}
Survival of organisms in polluted habitats is a key factor regarding their long-term population persistence. To avoid harmful physiological effects of pollutants' accumulation in organisms, decontamination and excretion could be effective mechanisms. Among invertebrates, ground beetles are reliable indicators of environmental pollution. Published results, however, are inconsistent, as some studies showed effective decontamination and excretion of pollutants, while others demonstrated severe toxic symptoms due to extreme accumulation. Using ground beetles as model organisms, we tested our pollution intensity-dependent disposal hypothesis for five pollutants $(\mathrm{Cd}, \mathrm{Cu}, \mathrm{Mn}, \mathrm{Pb}$, and $\mathrm{Zn}$ ) among four soil pollution intensity levels (low, moderate, high, and extreme) by categorical meta-analysis on published data. According to our hypothesis, decontamination and excretion of pollutants in ground beetles are effective in lowly or moderately polluted habitats, while disposal is ineffective in highly or extremely polluted ones, contributing to intense accumulation of pollutants in ground beetles. In accordance with the hypothesis, we found that in an extremely polluted habitat, accumulation of $\mathrm{Cd}$ and $\mathrm{Pb}$ in ground beetles was significantly higher than in lowly polluted ones. These findings may suggest the entomoremediation potential of ground beetles in an extremely polluted environment.
\end{abstract}

Keywords Bioindicator $\cdot$ Carabid $\cdot$ Contamination $\cdot$ Detoxification mechanism $\cdot$ Soil pollution

\section{Introduction}

Habitat pollution poses a huge risk to organisms because of the direct and/or indirect contact with the contaminated environment (Ciadamidaro et al. 2017; Touceda-González et al. 2017). Among negative effects, restricted range and disappearance are common phenomena, while in the cases of certain species and intensities of pollution, survival could also be endangered (Acevedo-Whitehouse and Duffus 2009). Based

Responsible editor: Philippe Garrigues

Electronic supplementary material The online version of this article (https://doi.org/10.1007/s11356-019-06294-5) contains supplementary material, which is available to authorized users.

Edina Simon

edina.simon@gmail.com

1 Department of Ecology, University of Debrecen, Egyetem tér 1, Debrecen H-4032, Hungary

2 MTA-DE Biodiversity and Ecosystem Services Research Group, Egyetem tér 1, Debrecen H-4032, Hungary on this, monitoring the fate of pollutants in ecosystems is highly important during environmental risk studies.

Responses of organisms to the metal pollution are greatly dependent on species and several other factors, such as form and concentration of metals, time of exposure, and $\mathrm{pH}$ conditions, which are closely related to the bioavailability of metals (Ashraf et al. 2012; Jaishankar et al. 2014; Rengel 2015). Furthermore, there are differences in the fate and regulation of essential (e.g., $\mathrm{Cu}, \mathrm{Mn}$, and $\mathrm{Zn}$ ) and non-essential (e.g., $\mathrm{Cd}$ and $\mathrm{Pb}$ ) metals in organisms, which is also a factor to consider (Hejna et al. 2018). Species that are able to indicate changes in environmental conditions like elevated metal concentrations are called bioindicators (Uehara-Prado et al. 2009; Parmar et al. 2016). This potential can manifest itself as the absence or presence of species, or as altered physiological and/or morphological characteristics (Bednarska et al. 2016). In metal-polluted environments, these possible responses are usually coupled with increased metal concentrations in tissues (Khan et al. 2015; Tőzsér et al. 2017; Papp et al. 2018; Mukhtorova et al. 2019).

Several studies have investigated the potential of terrestrial invertebrates to assess the degree of soil metal pollution 
(Mazzei et al. 2014; Xu et al. 2016a), among which ground beetles (Carabidae) are extensively studied indicator organisms (Rainio and Niemelä 2003; Pearce and Venier 2006; Rahim et al. 2013; Ghannem et al. 2018). Furthermore, they are potential candidates in entomoremediation (Ewuim 2013). Ground beetles are one of the most studied taxon due to their high general abundance in most habitats (Read et al. 1987; Magura et al. 2017) and diverse food preference (Kulkarni et al. 2017), where the latter results in nutrient and metal uptake from various sources (Purchart and Kula 2007). In addition, ground beetles are easy to collect, while the taxonomic history of species is well documented (Hůrka 1996; Lövei and Sunderland 1996). However, in terms of their metal uptake, assessment of beetles is quite contradictory. Besides experimental designs and methods used in individual publications, results on metal accumulation are further influenced by several factors such as feeding preference (carnivorous, herbivorous, and omnivorous), breeding type (spring breeder and autumn breeder), and developmental stage (egg, larva, pupa, and adult) as well as physiology and sex (Skalski et al. 2010; Simon et al. 2016). Furthermore, seasonal changes can also affect beetles' body metal concentrations (Butovsky 2011).

Metal accumulation was widely investigated and found to be varied by ground beetle species, while the accumulation potential of a certain species was also assessed inconsistently in previous publications. In comparison with other taxa, Heikens et al. (2001) found that the general metal concentration in ground beetles was significantly lower than that in spiders. As a possible reason, Kramarz (1999) attributed the relatively low metal concentration in ground beetles to the efficient decontamination and excretion mechanism of the digestive system. Based on these abilities, Butovsky (2011) referred to ground beetles as insects with generally low metal accumulation potential. It was previously demonstrated by van Straalen and van Wensem (1986) that $\mathrm{Cd}$ and $\mathrm{Pb}$ were accumulated in ground beetles in much lower concentrations than $\mathrm{Cu}$ and $\mathrm{Zn}$. Involving ten ground beetle species, Purchart and Kula (2007) observed significant interspecific differences in $\mathrm{Cd}, \mathrm{Cu}, \mathrm{Mn}$, and $\mathrm{Pb}$ accumulation. Furthermore, studying 28 ground beetle species, Stepanov et al. (1987) found major differences in metal accumulation between Carabus and Pterostichus species.

In addition, responses of ground beetles to metal stress were reported to be also inconsistent among studies. Monitoring Pterostichus oblongopunctatus individuals, Bednarska et al. (2016) reported severe gut degeneration as a result of $\mathrm{Cd}, \mathrm{Ni}$, and $\mathrm{Zn}$ pollution; however, the contribution of these metals to the development of the symptom was different. Furthermore, in the case of $\mathrm{Zn}$ pollution, Kramarz and Laskowski (1997) found a decrease in egg numbers laid by Poecilus cupreus. In contrast, in the case of P. oblongopunctatus, Lagisz and Laskowski (2008) observed increased egg production and decreased egg quality (hatchability) in metal-polluted areas compared to unpolluted ones. Lagisz et al. (2005) found that ground beetle species did not develop a successful adaptation mechanism to the toxic environmental conditions in metal-polluted habitats. In contrast, Zygmunt et al. (2006) demonstrated higher body mass of P. oblongopunctatus in the polluted areas than in an area with lower $\mathrm{Cd}, \mathrm{Pb}$, and $\mathrm{Zn}$ concentrations. It was explained by advanced metal tolerance and altered interspecific competition characteristics.

In the present study, ground beetles are used as model organisms to test our pollution intensity-dependent disposal hypothesis for five pollutants $(\mathrm{Cd}, \mathrm{Cu}, \mathrm{Mn}, \mathrm{Pb}$, and $\mathrm{Zn})$ among four soil pollution intensity levels (low, moderate, high, and extreme) by categorical meta-analysis on published data. Studied metals were involved in this study due to their major importance in various environmental processes, and due to being the only metals with sufficient data amount for these analyses. We hypothesized that inconsistencies in published results concerning decontamination, excretion, and accumulation of pollutants in ground beetles should have arisen from various pollution intensities of habitats. Based on our pollution intensity-dependent disposal hypothesis, we assumed that decontamination and excretion of pollutants in ground beetles are effective in lowly or moderately polluted habitats, while disposal is ineffective in highly or extremely polluted ones, contributing to intense accumulation of pollutants in ground beetles.

\section{Materials and methods}

\section{Literature search and data selection}

Data for the meta-analysis were collected by a literature search on Web of Science for the period 1975-2018. The following search terms were used: TOPIC $=($ metal $)$ AND TOPIC $=$ (accumulat* OR stor* OR accru* OR collect* OR aggregat* OR accret* OR buil* OR grow* OR inflat* OR add*) AND TOPIC $=\left(\right.$ carabid $^{*}$ OR ground beetle* $)$. For further, relevant publications, we revised the references of publications resulted in the search. To be suitable for the meta-analysis, publications had to publish metal $(\mathrm{Cd}, \mathrm{Cu}, \mathrm{Mn}, \mathrm{Pb}$, and $\mathrm{Zn}$ ) concentrations ( \pm SD with sample sizes) in one or more ground beetle species reared/found in unpolluted (control) vs. polluted habitats. Habitat pollution levels were determined by soil pollution levels; thus, publications had to report data on soil metal concentrations. Studies in which ground beetles had been fed contaminated food were excluded from the analyses. To get a comprehensive view of the metal accumulation potential of ground beetles, studied species were analyzed collectively. 


\section{Statistical analyses}

For each unpolluted-to-polluted comparison, a common effect size, the unbiased standardized mean difference (Hedges' $g$ ), was calculated between unpolluted and polluted ground beetle groups:

$g=J \frac{\overline{X_{\mathrm{U}}}-\overline{X_{\mathrm{P}}}}{S_{\text {within }}}$

$S_{\text {within }}=\sqrt{\frac{\left(n_{\mathrm{U}}-1\right) S_{\mathrm{U}}^{2}+\left(n_{\mathrm{P}}-1\right) S_{\mathrm{P}}^{2}}{n_{\mathrm{U}}+n_{\mathrm{P}}-2}}$

$J=1-\frac{3}{4\left(n_{\mathrm{U}}+n_{\mathrm{P}}-2\right)-1}$,

where $\overline{X_{\mathrm{U}}}$ and $\overline{X_{\mathrm{P}}}$ are the mean metal concentrations (mg $\mathrm{kg}^{-1}$, dry matter) in ground beetle species reared/found in unpolluted (U) and polluted (P) habitats, $n_{\mathrm{U}}$ and $n_{\mathrm{P}}$ are the sample sizes of ground beetles from unpolluted (U) and polluted (P) habitats, and $S_{\mathrm{U}}$ and $S_{\mathrm{P}}$ are their standard deviations. A negative $g$ value refers to higher metal concentration in ground beetles from polluted than from unpolluted soil.

We used subgroup meta-analysis to determine whether metal accumulation was similar among the differently polluted habitats. The subgroups were the habitats with different pollution intensity levels. Pollution levels were determined by the calculation of the pollution index (PI), which refers to the ratio of the detected and the background metal concentration in soils (Faiz et al. 2009):

$\mathrm{PI}=\frac{M_{\mathrm{c}}}{B_{\mathrm{c}}}$,

where $M_{\mathrm{c}}$ is the measured metal concentration in soil (reported in the given paper) and $B_{\mathrm{c}}$ is the background metal concentration in soil ( $\mathrm{mg} \mathrm{kg}^{-1}$, dry matter). Based on this calculation, pollution intensity levels were determined by the following: PI $\leq 1$ (low), $1 \leq \mathrm{PI} \leq 2$ (moderate), $2 \leq \mathrm{PI} \leq 5$ (high), and $\mathrm{PI} \geq 5$ (extreme) (Lu et al. 2007; Simon et al. 2013). Background metal concentrations were used from Geochemical Atlas of Europe Part 1 (Salminen et al. 2006).

We estimated the overall effect and examined the effects of moderators (pollution levels) using a random-effects model. We used a random-effects model because studies were not expected to estimate a common effect size due to variability in locations, habitats, and other conditions and methods used in the individual studies (Borenstein et al. 2009). Randomeffects models are more plausible than fixed-effect ones and also attribute the distribution of effect sizes to real differences among studies and do not assume sampling error as the only source of differences in effect sizes between studies (Borenstein et al. 2009). The mean effect size was defined as statistically significant if the $95 \%$ bootstrap confidence interval (CI; calculated with 999 iterations) did not include zero.

We investigated whether effect sizes were homogenous or varied across studies (i.e., if there was heterogeneity), since if the effect sizes vary across studies, a fundamentally different interpretation is needed compared to consistent effect sizes. To assess the heterogeneity of effects between studies, complementary measures of heterogeneity, $Q, T^{2}$, and $I^{2}$, were calculated (Borenstein et al. 2009). Further, we partitioned the total variance $\left(Q_{\text {total }}\right)$ into within-group $\left(Q_{\text {within }}\right)$ and betweengroup $\left(Q_{\text {between }}\right)$ variances using a $Q$-test based on analysis of variance. Then, these different components of variance were tested for statistical significance (Borenstein et al. 2009). In the case of significant variance between groups $\left(Q_{\text {between }}\right)$, metal accumulation of beetles from polluted habitats (soils) was significantly different according to the pollution intensity of the habitat. In order to evaluate the proportion of true variance explained by the covariates (subgroup classification), the $R^{2}$ was calculated (Borenstein et al. 2009). During calculations, subgroups with less than three cases were excluded from subgroup analyses, if a restricted amount of data was presented.

In meta-analyses, publication bias resulting in missing studies and potentially biased effect sizes are frequent issues (Borenstein et al. 2009). Hence, we tested publication bias by using funnel plots and Egger's test (Borenstein et al. 2009). By significant asymmetry, we used the trim-and-fill method (Duval and Tweedie 2000). This method calculates the number of missing studies and estimates their effect sizes as well as standard errors. After this, the resulted missing studies are added to the data set of the meta-analysis, and the summary effect size is re-computed. This method yields an unbiased estimate of the summary effect size (Borenstein et al. 2009). Meta-analyses, heterogeneity measures, and assessment of publication bias were completed by the MAd and metafor packages (Viechtbauer 2010; Del Re and Hoyt 2014) operated in the $\mathrm{R}$ version 3.5.0 ( $\mathrm{R}$ Core Team 2018).

\section{Results}

\section{Literature search and data selection}

The literature search yielded 72 publications, out of which, after checking also their reference sections, six papers were found that reported metal $(\mathrm{Cd}, \mathrm{Cu}, \mathrm{Mn}, \mathrm{Pb}$, and $\mathrm{Zn})$ concentrations ( \pm SD with sample sizes) in one or more ground beetle species from both unpolluted (control) and polluted habitats (soils) (Supplementary Materials Table A.1). From applicable 
publications, 146 comparisons were recovered. In these papers, 10 carnivorous ground beetle species were studied (Supplementary Materials Table A.1). In the six papers, soil metal concentrations varied between wide ranges: 0.24 $81.9 \mathrm{mg} \mathrm{kg}^{-1}$ for $\mathrm{Cd}, 6.5-46.9 \mathrm{mg} \mathrm{kg}^{-1}$ for $\mathrm{Cu}, 309-5827$ $\mathrm{mg} \mathrm{kg}^{-1}$ for $\mathrm{Mn}, 54.8-2635 \mathrm{mg} \mathrm{kg}^{-1}$ for $\mathrm{Pb}$, and $22.5-$ $10454 \mathrm{mg} \mathrm{kg}^{-1}$ for Zn. Based on pollution index (PI) calculations, data were available from habitats with low and extreme pollution intensities for $\mathrm{Mn}$ and $\mathrm{Pb}$; moderate and extreme pollution intensities for $\mathrm{Cd}$; low, high, and extreme pollution intensities for $\mathrm{Zn}$; and low, moderate, high, and extreme pollution intensities for $\mathrm{Cu}$.

\section{Metal accumulation in beetles}

\section{Accumulation of $\mathrm{Cd}$}

In the case of $\mathrm{Cd}$, data were available only from habitats with moderate and extreme pollution intensities. In extremely polluted habitats, ground beetles accumulated $\mathrm{Cd}$ in significantly $(p<0.05)$ higher concentrations than individuals in unpolluted habitats. The general $\mathrm{Cd}$ accumulation potential of ground beetles was significantly higher in polluted than in unpolluted habitats (Fig. 1 and Supplementary Materials Tables B.1-2).

In the overall model, total heterogeneity was significant and significant residual, unexplained heterogeneity was also found (Supplementary Materials Table B.1-2). In the funnel plot, significant asymmetry was found by the random-effects version of Egger's test, while it was not found by the classical version. In addition, according to the trim-and-fill method, the estimated number of missing values was 0 (Supplementary Materials C.1).

\section{Accumulation of $\mathrm{Cu}$}

In the case of $\mathrm{Cu}$, data were available from habitats with low, moderate, high, and extreme pollution intensities. Ground beetles accumulated $\mathrm{Cu}$ in higher concentrations in polluted habitats than in unpolluted ones; however, the differences were insignificant by either of the pollution intensity levels (Fig. 2 and Supplementary Materials Tables B.3-4).

In the overall model, total heterogeneity was significant and significant residual, unexplained heterogeneity was also found (Supplementary Materials Table B.3-4). In the funnel plot, significant asymmetry was found by the random-effects version of Egger's test, while it was not found by the classical version. In addition, according to the trim-and-fill method, the estimated number of missing values was 0 (Supplementary Materials C.2).

\section{Accumulation of $\mathrm{Mn}$}

In the case of $\mathrm{Mn}$, data were available only from habitats with low and extreme pollution intensities. Ground beetles accumulated $\mathrm{Mn}$ in higher concentrations in polluted habitats than in unpolluted ones; however, differences were insignificant by either of the pollution intensity levels (Fig. 3 and Supplementary Materials Tables B.5-6).

In the overall model, total heterogeneity was significant and significant residual, unexplained heterogeneity was also found (Supplementary Materials Table B.5-6). In the funnel plot, neither the random-effects version nor the classical version of Egger's test showed significant asymmetry. In addition, according to the trim-and-fill method, the estimated number of missing values was 0 (Supplementary Materials C.3).

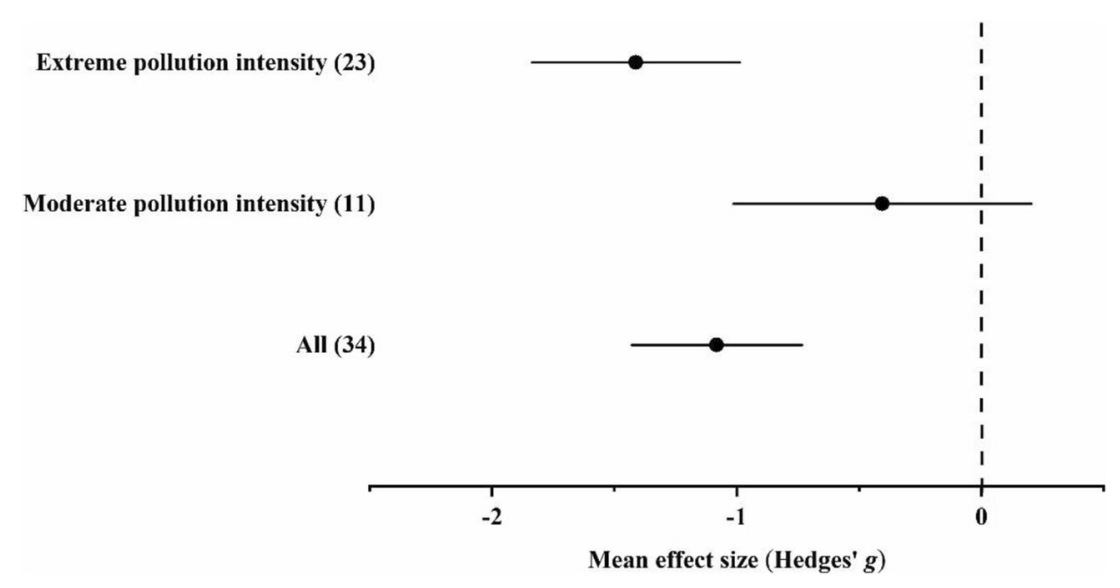

Fig. 1 Mean effect sizes (mean Hedges' $g \pm 95 \%$ confidence interval) for $\mathrm{Cd}$ concentrations in ground beetle individuals living in unpolluted and polluted habitats. Values in brackets refer to the number of comparisons from which the mean effect size was calculated. A negative $g$ value means

higher $\mathrm{Cd}$ concentration in beetles living in polluted habitats than in unpolluted ones. The mean effect size was considered statistically significant if the $95 \%$ bootstrap confidence interval (CI) did not include zero 
Fig. 2 Mean effect sizes (mean Hedges' $g \pm 95 \%$ confidence interval) for $\mathrm{Cu}$ concentrations in ground beetle individuals living in unpolluted and polluted habitats. Values in brackets refer to the number of comparisons from which the mean effect size was calculated. A negative $g$ value means higher $\mathrm{Cu}$ concentration in beetles living in polluted habitats than in unpolluted ones. The mean effect size was considered statistically significant if the $95 \%$ bootstrap confidence interval (CI) did not include zero
Extreme pollution intensity (5)

High pollution intensity (7)

Moderate pollution intensity (7)

Low pollution intensity (12)

All (31)

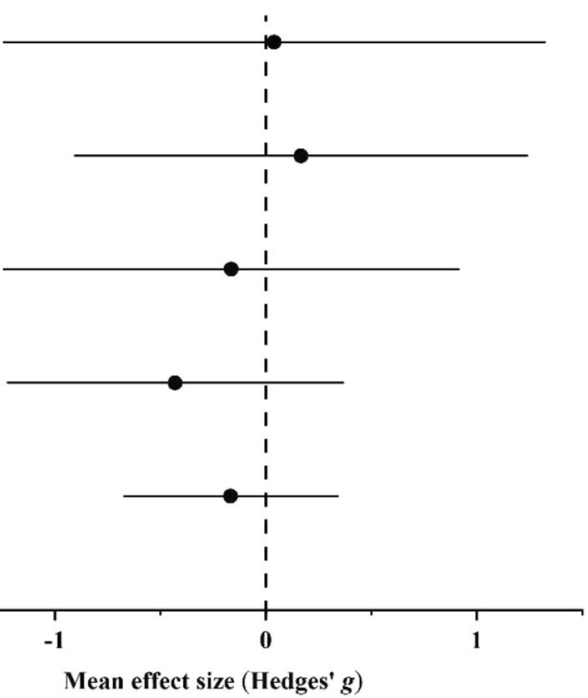

\section{Accumulation of $\mathrm{Zn}$}

In the case of $\mathrm{Pb}$, data were available only from habitats with low and extreme pollution intensities. In extremely polluted habitats, ground beetles accumulated $\mathrm{Pb}$ in significantly $(p<$ 0.05 ) higher concentrations than individuals in unpolluted habitats. The general $\mathrm{Pb}$ accumulation potential of ground beetles was significantly higher in polluted than in unpolluted habitats (Fig. 4 and Supplementary Materials Tables B.7-8).

In the overall model, total heterogeneity was significant and significant residual, unexplained heterogeneity was also found (Supplementary Materials Table B.7-8). In the funnel plot, significant asymmetry was found both by the randomeffects and classical version of Egger's test. In addition, according to the trim-and-fill method, the estimated number of missing values was 0 (Supplementary Materials C.1).
In the case of Zn, data were available from habitats with low, high, and extreme pollution intensities. Ground beetles accumulated $\mathrm{Zn}$ in higher concentrations in polluted habitats than in unpolluted ones; however, the differences were insignificant by either of the pollution intensity levels (Fig. 5 and Supplementary Materials Tables B.9-10).

In the overall model, total heterogeneity was significant and significant residual, unexplained heterogeneity was also found (Supplementary Materials Table B.9-10). In the funnel plot, significant asymmetry was found by the random-effects version of Egger's test, while it was not found by the classical version. In addition, according to the trim-and-fill method, the estimated number of missing values was 0 (Supplementary Materials C.2).

Extreme pollution intensity (7)

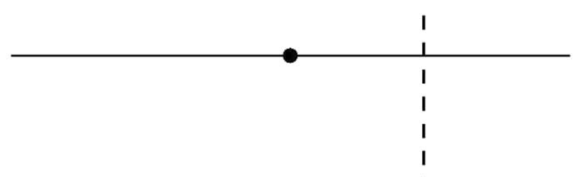

Low pollution intensity (12)

All (19)

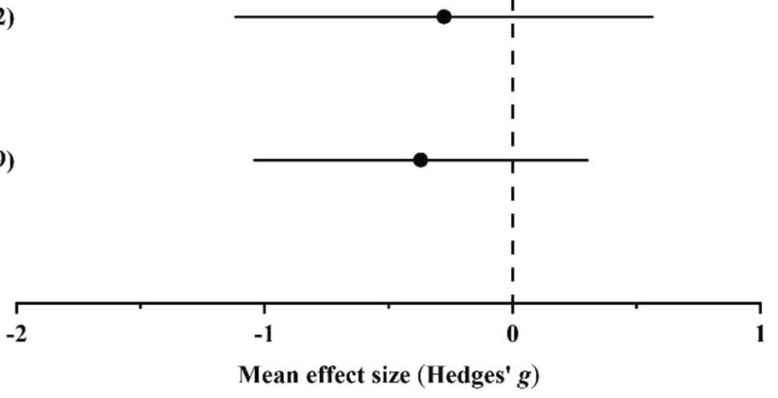

Fig. 3 Mean effect sizes (mean Hedges' $g \pm 95 \%$ confidence interval) for Mn concentrations in ground beetle individuals living in unpolluted and polluted habitats. Values in brackets refer to the number of comparisons from which the mean effect size was calculated. A negative $g$ value means higher Mn concentration in beetles living in polluted habitats than in unpolluted ones. The mean effect size was considered statistically significant if the $95 \%$ bootstrap confidence interval (CI) did not include zero 


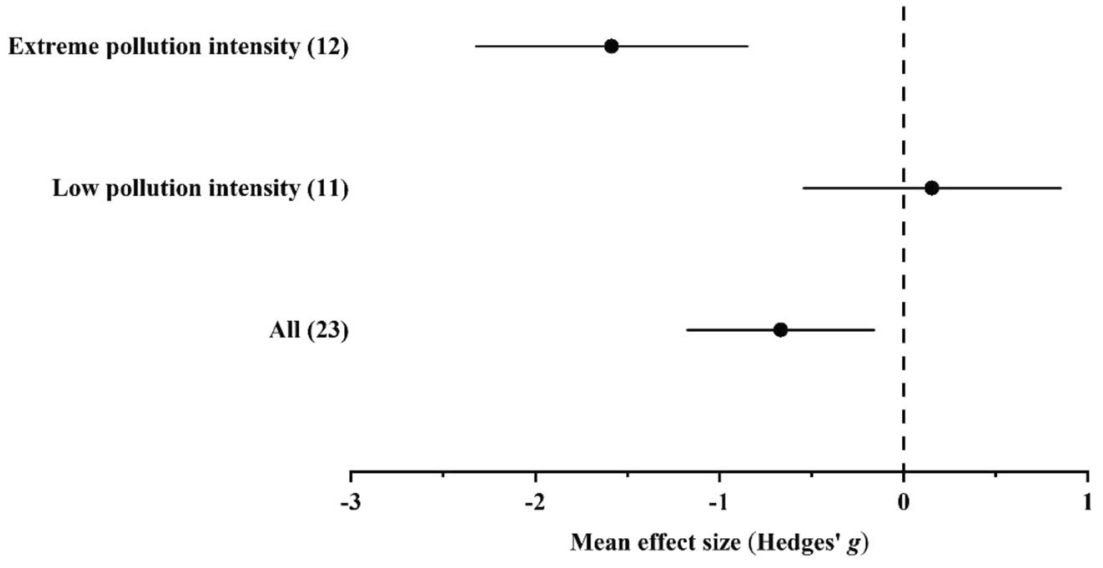

Fig. 4 Mean effect sizes (mean Hedges' $g \pm 95 \%$ confidence interval) for $\mathrm{Pb}$ concentrations in ground beetle individuals living in unpolluted and polluted habitats. Values in brackets refer to the number of comparisons from which the mean effect size was calculated. A negative $g$ value means

\section{Discussion}

In line with our hypothesis, we demonstrated that ground beetles should have an effective detoxification mechanism by low soil $\mathrm{Cd}, \mathrm{Pb}$, and $\mathrm{Zn}$ pollution intensity, because we found low metal accumulation in their tissues. However, our result also indicated that the mechanism may be significantly inhibited by an extreme level of soil pollution.

In comparison with control environmental conditions, we found that ground beetles living in extremely polluted habitats accumulated $\mathrm{Cd}$ in significantly higher concentrations than those from habitats with low pollution intensity. A high concentration of $\mathrm{Cd}$ in ground beetles under highly toxic conditions was also found by Kramarz (1999). The author demonstrated that ground beetles, which were exposed to $\mathrm{Cd}$ contaminated food, showed continuously increasing body metal concentration until the end of exposure. Then, due to higher $\mathrm{Pb}$ concentration in beetles living in polluted habitats than in unpolluted ones. The mean effect size was considered statistically significant if the $95 \%$ bootstrap confidence interval (CI) did not include zero

the efficient inherent decontamination mechanism, $\mathrm{Cd}$ concentration rapidly decreased to pre-treatment levels. In contrast, Maryański et al. (2002) found that ground beetles were able to regulate excess $\mathrm{Cd}$ uptake with only a moderate level of decontamination efficiency. They concluded that the energy demand of the detoxification mechanism was high enough to influence reproduction success significantly. As a further consequence, Lindquist and Block (2001) observed that ground beetles living in the highly metal-polluted environment had much lower body fat concentration than individuals from unpolluted habitats, which was explained by the increased energy demand of metal detoxification. Similarly, Butovsky (1997) highlighted the commonly low accumulation propensity of $\mathrm{Cd}$ in ground beetles. Furthermore, Lodenius et al. (2009) noticed that compared to control (unpolluted) conditions, the $\mathrm{Cd}$ concentration in beetles remained low even after soil fertilization and the simultaneous increase in the amount

Extreme pollution intensity (17)

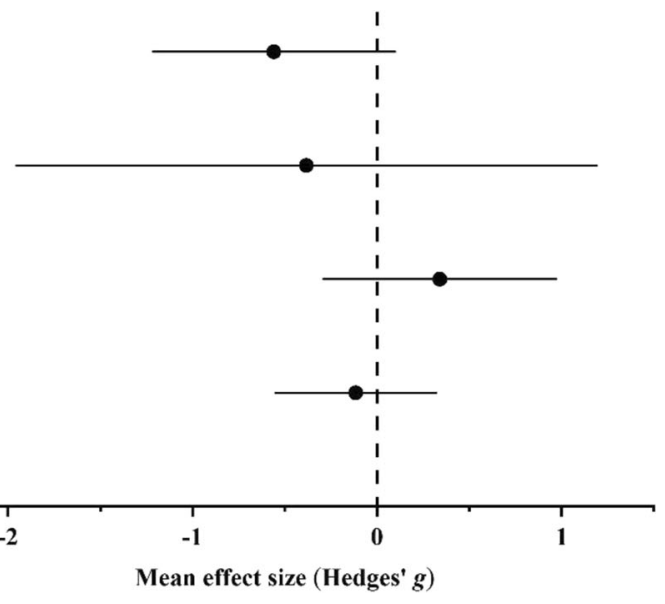

Fig. 5 Mean effect sizes (mean Hedges' $g \pm 95 \%$ confidence interval) for $\mathrm{Zn}$ concentrations in ground beetle individuals living in unpolluted and polluted habitats. Values in brackets refer to the number of comparisons from which the mean effect size was calculated. A negative $g$ value means

higher $\mathrm{Zn}$ concentration in beetles living in polluted habitats than in unpolluted ones. The mean effect size was considered statistically significant if the $95 \%$ bootstrap confidence interval (CI) did not include zero 
of available Cd. Also, in accordance with our observations, Purchart and Kula (2007) demonstrated a generally low Cd accumulation potential in several ground beetle species collected from a habitat with a low pollution level. Thus, it was possible in extremely polluted habitats that continuous $\mathrm{Cd}$ exposure, coupled with restricted detoxification success, could contribute to the high body concentration found in ground beetles. In habitats with low pollution intensity, reduced accumulation and increased detoxification (excretion) intensity (Kramarz 1999) may explain low body Cd concentrations presented in this paper.

We observed that accumulation of $\mathrm{Pb}$ in ground beetles was considerable in extremely polluted habitats. In contrast with our findings, Butovsky (1997) concluded that $\mathrm{Pb}$ and $\mathrm{Cd}$ have the lowest accumulation potential in ground beetle species. In the cases of several terrestrial invertebrates, Didur et al. (2017) also demonstrated that the studied species had generally low $\mathrm{Pb}$ accumulation rates, regardless of their position in the trophic chain. As presented in this paper, Zhang et al. (2017) also found increased $\mathrm{Pb}$ concentration in Enchytraeus crypticus individuals inhabiting heavily polluted habitats. They emphasized that after the 14-day accumulation period, individuals could regulate body metal concentration during an elimination period and decrease it to a constant low level with their successful excretion mechanism. The successful decontamination ability of ground beetles is based on the low pollution intensity and restricted availability of $\mathrm{Pb}$ in soils along with the low $\mathrm{Pb}$ accumulation. As for soil conditions, $\mathrm{Pb}$ is a metal with very low mobility; however, its mobility depends on such soil properties as $\mathrm{pH}$ (Ashraf et al. 2012). Based on this, $\mathrm{Pb}$ mobility could be increased by acidic soil $\mathrm{pH}$ values (Jelaska et al. 2007). Thus, high mobility of $\mathrm{Pb}$ could explain the significantly higher $\mathrm{Pb}$ concentration in ground beetles. This result is in correspondence with the observations of Heikens et al. (2001), who found a positive correlation between soil and invertebrate body metal concentrations in heavily polluted habitats. Van Straalen et al. (2001) also highlighted the notable $\mathrm{Pb}$-accumulating potential of ground beetles in extremely polluted habitats. As a conclusion, it could be recognized that $\mathrm{Pb}$ accumulation is dependent on several factors and is greatly variable among studies.

In our study, we found the highest degree of $\mathrm{Zn}$ accumulation in ground beetle species in extremely polluted conditions. It was observed by Mozdzer et al. (2003) that Zn pollution induced developmental abnormalities in P. oblongopunctatus individuals similar to those caused by $\mathrm{Cd}$. However, Grodzinska et al. (1987) demonstrated that excretion of $\mathrm{Zn}$ in terrestrial species can be more successfully regulated than that of non-essential metals. In addition, Kramarz (1999) revealed a significant effect of Cd-Zn co-contamination neither on $\mathrm{Cd}$ nor on $\mathrm{Zn}$ accumulation in ground beetles, indicating a certain degree of correlation between the accumulation mechanisms of these two metals. This latter relation is in accordance with our results, regarding $\mathrm{Cd}$ and $\mathrm{Zn}$ accumulations in extremely polluted habitats. Similar to our findings, Gongalski and Butovsky (1998) observed no significant difference in $\mathrm{Zn}$ accumulation of Poecilus cupreus between highly polluted and unpolluted soils. Low $\mathrm{Zn}$ concentrations in beetles in slightly polluted habitats could be the result of several factors. For instance, Lock et al. (2001) found that ground beetles collected from differently polluted habitats could have low body $\mathrm{Zn}$ concentration due to the efficient regulatory and decontamination mechanism of their preys. In line with that, we assume that carnivorous species involved in these analyses had relatively high $\mathrm{Zn}$ accumulation potential, compared to non-studied omnivore species. This assumption was previously confirmed by Purchart and Kula (2007), who highlighted that $\mathrm{Zn}$ uptake is more intensive in carnivorous than in herbivorous and omnivorous species.

Unlike $\mathrm{Cd}, \mathrm{Pb}$, and $\mathrm{Zn}$, we found insignificant differences in $\mathrm{Cu}$ accumulation of ground beetles between the polluted and unpolluted habitats. An insignificant trend with generally higher $g$ values for $\mathrm{Cu}$ from low towards extreme pollution intensity levels may indicate a decreasing accumulation intensity in beetles. However, the accumulation pattern of $\mathrm{Cu}$ depends basically on the mass/size of the ground beetles, with a lower accumulation rate in large species than in small-sized ones (Butovsky 2011). In our study, concentrations of $\mathrm{Cu}$ were calculated for both medium-sized and large-sized ground beetles, probably causing a different trend in accumulation intensity of $\mathrm{Cu}$ compared to those of $\mathrm{Cd}, \mathrm{Pb}$, and $\mathrm{Zn}$. Moreover, for invertebrates, Lukáň (2009) emphasized that $\mathrm{Cu}$ is an essential element with special accumulation and regulation patterns and has higher body element concentration compared to non-essential metals like $\mathrm{Cd}$. In contrast with our results, Lukáň (2009) indicated a general positive correlation between soil and body $\mathrm{Cu}$ concentrations. In addition, Talarico et al. (2014) also observed a close relationship in $\mathrm{Cu}$ concentration between soil and large-sized Carabus lefebvrei individuals. However, Smolders et al. (2012) highlighted that the availability of $\mathrm{Cu}$ in soils could be highly variable depending on the form and exposure of the metal. In association with these results, Bednarska and Stępień (2015) found that red flour beetles (Tribolium castaneum) responded to a considerably elevated soil $\mathrm{Cu}$ concentration only with slightly increased body concentration. The authors attributed this phenomenon to the efficient internal regulation route, as previously indicated by Lukán̆ (2009). In white rat springtail (Folsomia candida) individuals, Ardestani and van Gestel (2013) found similar results between habitats with high and low $\mathrm{Cu}$ pollution. Based on these results, we assume that insignificant differences in ground beetle body $\mathrm{Cu}$ concentrations could be related to the mass/size and detoxification mechanism of the studied species, complemented by a habitat-specific availability of soil $\mathrm{Cu}$. 
It was presented in this study that ground beetles did not accumulate significantly higher concentrations of $\mathrm{Mn}$ in polluted habitats than in unpolluted ones. Furthermore, studying the effect of Mn accumulation on the uptake of other metals in ground beetles, Purchart and Kula (2007) demonstrated a significant positive correlation between the accumulations of $\mathrm{Mn}$ and $\mathrm{Cu}$. We indicated that the two metals had similar accumulation patterns in the studied ground beetle species. Between the accumulations of $\mathrm{Mn}$ and $\mathrm{Cd}$ in terrestrial organisms, Huang et al. (2017) found a negative correlation. Similarly, we observed that ground beetles had high $\mathrm{Cd}$ and low Mn accumulation potentials in habitats with high pollution intensity. Knowing that each of the species involved in this meta-analysis is carnivorous, metal concentrations in individuals could arise from consuming preys feeding on plants with the contrasting $\mathrm{Mn}-\mathrm{Cd}$ accumulation pattern. Thus, indirect uptake of metals could be realized through the food chain by the biomagnification process (Conti et al. 2017). Investigating metal accumulation in several arthropod species, Janssen and Hogervorst (1993) found no major differences in Mn concentration of species collected from polluted and reference areas. It was previously indicated that despite being present in soils in sufficient concentrations, Mn availability to plants could be highly reduced by certain soil and plant characteristics (e.g., alteration of soil $\mathrm{pH}$, amount and quality root exudates; Rengel 2015). In contrast, Jelaska et al. (2007) found significant differences in soil $\mathrm{pH}$ between polluted and unpolluted habitats, while ground beetles did not respond to these altered environmental conditions with an increased rate of $\mathrm{Mn}$ accumulation. We assume that this kind of specific accumulation mechanism of essential Mn could be responsible for the limited concentration values in beetles.

Based on the meta-analysis, significant residual and unexplained heterogeneities were found, which indicated that besides pollution intensity levels there are several other factors that should be considered when assessing metal accumulation in ground beetles. Partition between available and total metal concentrations, and forms of metals in soils, are decisive respecting the accumulation in beetles and also in other organisms (Ignatowicz 2017). Additionally, other soil parameters such as soil $\mathrm{pH}$, loam content, and hydrological conditions also influence the migration and uptake of metals considerably (Rakesh Sharma and Raju 2013; Xu et al. 2016b). In addition, ground beetle species and their specific inherent characteristics determine the accumulation pattern significantly (Avgin and Luff 2010; Butovsky 2011). It was previously demonstrated that body size (Butovsky 2011), sex (Stepanov et al. 1987; Rabitsch 1995; Lagisz et al. 2010), feeding preference (Migula et al. 2004; Purchart and Kula 2007), breeding type (Skalski et al. 2010), and developmental stage (Bayley et al. 1995; Bednarska et al. 2011) are of great importance regarding metal uptake in beetles. Exposure time is also a major factor to consider (Spurgeon and Hopkin 1999; Prasifka et al. 2008). A comprehensive meta-analysis involving all the above factors influencing metal uptake could be a major step towards more thoroughly assessing of the metal accumulation pattern in ground beetles.

\section{Conclusions}

We found that metal accumulation of ground beetles was greatly variable depending on the studied metal and pollution intensity level. In habitats with a low pollution level, ground beetles can regulate their body metal concentration via a successful detoxification mechanism. In extremely polluted habitats, ground beetles showed a significant accumulation potential for $\mathrm{Cd}$ and $\mathrm{Pb}$, and a great accumulation potential for $\mathrm{Zn}$; thus, ground beetles were found to be good indicators of extreme soil metal pollution via metal uptake. Summarizing, our results suggest that ground beetles can effectively be used as a naturally available pollution indicator or bioassays of the level of soil pollution. Furthermore, ground beetles as entomoremediators may be useful in decontaminating soils extremely polluted by metals via sequestering metals in their tissues (Ewuim 2013).

Acknowledgments Open access funding provided by University of Debrecen (DE). We are grateful to the Hungarian Research Fund supporting the research (OTKA K-116639, NKFI KH 126477, and NKFI KH 126481). Authorship is by the "sequence by credit" (SDC) principle.

Open Access This article is distributed under the terms of the Creative Commons Attribution 4.0 International License (http:// creativecommons.org/licenses/by/4.0/), which permits unrestricted use, distribution, and reproduction in any medium, provided you give appropriate credit to the original author(s) and the source, provide a link to the Creative Commons license, and indicate if changes were made.

\section{References}

Acevedo-Whitehouse K, Duffus AJL (2009) Effects of environmental change on wildlife health. Philos T R Soc B 364:3429-3438. https://doi.org/10.1098/rstb.2009.0128

Ardestani MM, van Gestel CAM (2013) Dynamic bioavailability of copper in soil estimated by uptake and elimination kinetics in the springtail Folsomia candida. Ecotoxicology 22:308-318. https://doi.org/ 10.1007/s10646-012-1027-8

Ashraf MA, Maah MJ, Yusoff I (2012) Chemical speciation and potential mobility of heavy metals in the soil of former tin mining catchment. Sci World J 2012:125608-125611. https://doi.org/10.1100/2012/ 125608

Avgın SS, Luff ML (2010) Ground beetles (Coleoptera: Carabidae) as bioindicators of human impact. Mun Ent Zool 5:209-215

Bayley M, Baatrup E, Heimbach U, Bjerregaard P (1995) Elevated copper levels during larval development cause altered locomotor behaviour in the adult carabid beetle Pterostichus cupreus L. (Coleoptera: 
Carabidae). Ecotox Environ Safe 32:166-170. https://doi.org/10. 1006/eesa.1995.1098

Bednarska AJ, Stępień K (2015) Concentration dependent toxicokinetics of copper in the red flour beetle Tribolium castaneum (Coleoptera: Tenebrionidae). Ecotoxicology 24:1823-1830. https://doi.org/10. 1007/s10646-015-1518-5

Bednarska AJ, Brzeska A, Laskowski R (2011) Two-phase uptake of nickel in the ground beetle Pterostichus oblongopunctatus (Coleoptera: Carabidae): implications for invertebrate metal kinetics. Arch Environ Cont Tox 60:722-733. https://doi.org/10.1007/ s00244-010-9581-7

Bednarska AJ, Laskowski R, Pyza E, Semik D, Świątek Z, Woźnicka O (2016) Metal toxicokinetics and metal-driven damage to the gut of the ground beetle Pterostichus oblongopunctatus. Environ Sci Pollut R Int 23:22047-22058. https://doi.org/10.1007/s11356-016$7412-8$

Borenstein M, Hedges LV, Higgins JPT, Rothstein HR (2009) Introduction to meta-analysis. John Wiley \& Sons, Ltd, Chichester, UK

Butovsky RO (1997) Heavy metals and carabids (Coleoptera, Carabidae). Agrohimija 11:78-86

Butovsky RO (2011) Heavy metals in carabids (Coleoptera, Carabidae). Zookeys 100:215-222. https://doi.org/10.3897/zookeys.100.1529

Ciadamidaro L, Puschenreiter M, Santner J, Wenzel WW, Madejón P, Madejón E (2017) Assessment of trace element phytoavailability in compost amended soils using different methodologies. J Soil Sediment 17:1251-1261. https://doi.org/10.1007/s11368-0151283-3

Conti E, Dattilo S, Costa G, Puglisi C (2017) The ground beetle Parallelomorphus laevigatus is a potential indicator of trace metal contamination on the eastern coast of Sicily. Ecotox Environ Safe 135:183-190. https://doi.org/10.1016/j.ecoenv.2016.09.029

Del Re AC, Hoyt WT (2014) MAd: Meta-analysis with mean with mean differences. R package version 0.8-2. URL: http://cran.r-project.org/ web/packages/MAd.

Didur OA, Kulbachko YL, Gasso VY (2017) Accumulation of microelements by different invertebrate trophic groups on wasted lands. Ukr J Ecol 7:30-34. https://doi.org/10.15421/2017_83

Duval S, Tweedie R (2000) Trim and fill: a simple funnel-plot-based method of testing and adjusting for publication bias in meta-analysis. Biometrics 56:455-463. https://doi.org/10.1111/j.0006-341X. 2000.00455.x

Ewuim SC (2013) Entomoremediation - a novel in-situ bioremediation approach. Anim Res Int 10:1681-1684

Faiz Y, Tufail M, Javed MT, Chaudhry MM, Siddique N (2009) Road dust pollution of $\mathrm{Cd}, \mathrm{Cu}, \mathrm{Ni}, \mathrm{Pb}$ and $\mathrm{Zn}$ along Islamabad Expressway, Pakistan. Microchem J 92:186-192. https://doi.org/ 10.1016/j.microc.2009.03.009

Ghannem S, Touaylia S, Boumaiza M (2018) Beetles (Insecta: Coleoptera) as bioindicators of the assessment of environmental pollution. Hum Ecol Risk Assess 24:456-464. https://doi.org/10. 1080/10807039.2017.1385387

Gongalski KB, Butovsky RO (1998) Heavy metal pollution and carabid beetles (Coleoptera, Carabidae) in the vicinity of the Kosogorski metallurgic plant at Kosaya Gora. In: Butovsky RO, van Straalen NM (eds) Pollution-induced changes in soil invertebrate food-webs. Vrije Universiteit, Amsterdam and Moscow, p 55

Grodzinska K, Godzik B, Darowska E, Pawlowska B (1987) Concentrations of heavy metals in trophic chains of Niepolomice Forest, s. Poland. Ekol Pol 35:327-344

Heikens A, Peijnenburg WJGM, Hendriks AJ (2001) Bioaccumulation of heavy metals in terrestrial invertebrates. Environ Pollut 113:385393. https://doi.org/10.1016/S0269-7491(00)00179-2

Hejna M, Gottardo D, Baldi A, Dell'Orto V, Chieli F, Zaninelli M, Rossi L (2018) Review: nutritional ecology of heavy metals. Animal 8:115. https://doi.org/10.1017/S175173111700355X
Huang QN, An H, Yang YJ, Liang Y, Shao GS (2017) Effects of Mn-Cd antagonistic interaction on $\mathrm{Cd}$ accumulation and major agronomic traits in rice genotypes by different Mn forms. Plant Growth Regul 82:317-331. https://doi.org/10.1007/s10725-017-0261-8

Hůrka K (1996) Carabidae of the Czech and Slovak Republics. Zlin, Czech Republic, Kabourek

Ignatowicz K (2017) The impact of sewage sludge treatment on the content of selected heavy metals and their fractions. Environ Res 156: 19-22. https://doi.org/10.1016/j.envres.2017.02.035

Jaishankar M, Tseten T, Anbalagan N, Mathew BB, Beeregowda KN (2014) Toxicity, mechanism and health effects of some heavy metals. Interdiscip Toxicol 7:60-72. https://doi.org/10.2478/intox2014-0009

Janssen MPM, Hogervorst RF (1993) Metal accumulation in soil arthropods in relation to micro-nutrients. Environ Pollut 79:181-189. https://doi.org/10.1016/0269-7491(93)90068-Y

Jelaska LS, Blanuša M, Durbešić P, Jelaska SD (2007) Heavy metal concentrations in ground beetles, leaf litter, and soil of a forest ecosystem. Ecotox Environ Safe 66:74-81. https://doi.org/10.1016/j. ecoenv.2005.10.017

Khan A, Khan S, Khan MA, Qamar Z, Wagas M (2015) The uptake and bioaccumulation of heavy metals by food plants, their effects on plants nutrients, and associated health risk: a review. Environ Sci Pollut R 22:13772-13799. https://doi.org/10.1007/s11356-0154881-0

Kramarz P (1999) Dynamics of accumulation and decontamination of cadmium and zinc in carnivorous invertebrates 1: the ground beetle, Poecilus cupreus L. B Environ Contam Tox 63:531-537. https://doi. org/10.1007/s001289901013

Kramarz P, Laskowski R (1997) Effect of zinc contamination on life history parameters of a ground beetle, Poecilus cupreus. B Environ Contam Tox 59:525-530. https://doi.org/10.1007/ s001289900510

Kulkarni SS, Dosdall LM, Spence JR, Willenborg CJ (2017) Seed detection and discrimination by ground beetles (Coleoptera: Carabidae) are associated with olfactory cues. PLoS One 12:e0170593. https:// doi.org/10.1371/journal.pone. 0170593

Lagisz M, Laskowski R (2008) Evidence for between-generation effects in carabids exposed to heavy metals pollution. Ecotoxicology 17: 59-66. https://doi.org/10.1007/s10646-007-0176-7

Lagisz M, Kramarz P, Niklinska M (2005) Metal kinetics and respiration rates in $\mathrm{F} 1$ generation of carabid beetles (Pterostichus oblongopunctatus $\mathrm{F}$.) originating from metal-contaminated and reference areas. Arch Environ Con Tox 48:484-489. https://doi.org/10. 1007/s00244-004-0023-2

Lagisz M, Wolff K, Sanderson RA, Laskowski R (2010) Genetic population structure of the ground beetle, Pterostichus oblongopunctatus, inhabiting a fragmented and polluted landscape: evidence for sexbiased dispersal. J Insect Sci 10:105-120. https://doi.org/10.1673/ 031.010 .10501

Lindquist L, Block M (2001) Metal pollution and fat accumulation in the carabid beetle Pterostichus melanarius (Coleoptera, Carabidae). B Environ Contam Tox 66:184-188. https://doi.org/10.1007/ s0012800223

Lock K, Desender K, Janssen CR (2001) Effects of metal contamination on the activity and diversity of carabid beetles in an ancient $\mathrm{Pb}-\mathrm{Zn}$ mining area at Plombières (Belgium). Entomol Exp Appl 99:355360. https://doi.org/10.1023/A:1019247017108

Lodenius M, Josefsson J, Heliövaara K, Tulisalo E, Nummelin M (2009) Cadmium in insects after ash fertilization. Insect Sci 16:93-98. https://doi.org/10.1111/j.1744-7917.2009.00259.x

Lövei GL, Sunderland KD (1996) Ecology and behavior of ground beetles (Coleoptera: Carabidae). Annu Rev Entomol 41:231-256. https://doi.org/10.1146/annurev.en.41.010196.001311 
Lu Y, Zhu F, Chen J, Gan H, Guo Y (2007) Chemical fraction of heavy metals in urban soils of Guangzhou, China. Environ Monit Assess 134:429-439. https://doi.org/10.1007/s10661-007-9634-1

Lukán̆ M (2009) Heavy metals in alpine terrestrial invertebrates. Oecol Mont 18:31-38

Magura T, Lövei GL, Tóthmérész B (2017) Edge responses are different in edges under natural versus anthropogenic influence: a metaanalysis using ground beetles. Ecol Evol 7:1009-1017. https://doi. org/10.1002/ece3.2722

Maryański M, Kramarz P, Laskowski R, Niklińska M (2002) Decreased energetic reserves, morphological changes and accumulation of metals in carabid beetles (Poecilus cupreus L.) exposed to zinc- or cadmium-contaminated food. Ecotoxicology 11:127-139. https:// doi.org/10.1023/A:1014425113481

Mazzei V, Longo G, Brundo MV, Sinatra F, Copat C, Oliveri Conti G, Ferrante M (2014) Bioaccumulation of cadmium and lead and its effects on hepatopancreas morphology in three terrestrial isopod crustacean species. Ecotox Environ Safe 110:269-279. https://doi. org/10.1016/j.ecoenv.2014.09.015

Migula P, Łaszczyca P, Augustyniak M, Wilczek G, Rozpędek K, Kafel A, Wołoszyn M (2004) Antioxidative defence enzymes in beetles from a metal pollution gradient. Biologia 59:645654

Mozdzer TJ, Kramarz P, Piśkiewicz A, Niklińska M (2003) Effects of cadmium and zinc on larval growth and survival in the ground beetle, Pterostichus oblongopunctatus. Environ Int 28:737-742. https://doi.org/10.1016/S0160-4120(02)00107-1

Mukhtorova D, Hlava J, Száková J, Kubík Š, Vrabec V, Tlustoš P (2019) Risk element accumulation in Coleoptera and Hymenoptera (Formicidae) living in an extremely contaminated area - a preliminary study. Environ Monit Assess 191:432. https://doi.org/10.1007/ s10661-019-7584-z

Papp D, Simon E, Nagy L, Mizser Sz, Tóthmérész B (2018) The effect of urbanization on trace element concentration and symmetry of woodlice (Armadillidium vulgare Latreille, 1804). Biol Trace Elem Res 189:251-258. https://doi.org/10.1007/s12011-018-1454-3

Parmar TK, Rawtani D, Agrawal YK (2016) Bioindicators: the natural indicator of environmental pollution. Front Life Sci 9:110-118. https://doi.org/10.1080/21553769.2016.1162753

Pearce JL, Venier LA (2006) The use of ground beetles (Coleoptera: Carabidae) and spiders (Araneae) as bioindicators of sustainable forest management: a review. Ecol Indic 6:780-793. https://doi. org/10.1016/j.ecolind.2005.03.005

Prasifka JR, Lopez MD, Hellmich RL, Prasifka PL (2008) Effects of insecticide exposure on movement and population size estimates of predatory ground beetles (Coleoptera: Carabidae). Pest Manag Sci 64:30-36. https://doi.org/10.1002/ps.1460

Purchart L, Kula E (2007) Content of heavy metals in bodies of field ground beetles (Coleoptera, Carabidae) with respect to selected ecological factors. Polish J Ecol 55:305-314

R Core Team (2018) R: a language and environment for statistical computing. R Foundation for Statistical Computing, Vienna, Austria. URL: https://www.R-project.org/

Rabitsch WB (1995) Metal accumulation in arthropods near a lead/zinc smelter in Arnoldstein, Austria. I. Environ Pollut 90:21-37. https:// doi.org/10.1016/0269-7491(95)00005-C

Rahim J, Khan MR, Nazir N (2013) Systematic and abundance of ground beetles (Carabidae: Coleoptera) from District Poonch Azad Kashmir, Pakistan. IOSR J Agric Vet Sci 6:24-29. https://doi.org/ 10.9790/2380-0622429

Rainio J, Niemelä J (2003) Ground beetles (Coleoptera: Carabidae) as bioindicators. Biodivers Conserv 12:487-506. https://doi.org/10. 1023/A:1022412617568

Rakesh Sharma MS, Raju NS (2013) Correlation of heavy metal contamination with soil properties of industrial areas of
Mysore Karnataka, India by cluster analysis. Int Res J Environ Sci 2:22-27

Read HJ, Wheater CP, Martin MH (1987) Aspects of the ecology of Carabidae (Coleoptera) from woodlands polluted by heavy metals. Environ Pollut 48:61-76. https://doi.org/10.1016/0269-7491(87) 90086-8

Rengel Z (2015) Availability of Mn, Zn and Fe in the rhizosphere. J Soil Sci Plant Nut 15:397-409. https://doi.org/10.4067/S071895162015005000036

Salminen R, Plant J, Reeder S (2006) Geochemical atlas of Europe. Part 1, Background information, methodology and maps. Espoo, Finland. Geological Survey of Finland.

Simon E, Vidic A, Braun M, Fábián I, Tóthmérész B (2013) Trace element concentrations in soils along urbanization gradients in the city of Wien, Austria. Environ Sci Pollut R 20:917-924. https://doi.org/ 10.1007/s11356-012-1091-x

Simon E, Harangi S, Baranyai E, Braun M, Fábián I, Mizser Sz, Nagy L, Tóthmérész B (2016) Distribution of toxic elements between biotic and abiotic components of terrestrial ecosystem along an urbanization gradient: soil, leaf litter and ground beetles. Ecol Indic 60:258264. https://doi.org/10.1016/j.ecolind.2015.06.045

Skalski T, Stone D, Kramarz P, Lakowski R (2010) Ground beetle community responses to heavy metal stress. Baltic J Coleopterol 10:112

Smolders E, Oorts K, Lombi E, Schoeters I, Ma Y, Zrna S, McLaughlin MJ (2012) The availability of copper in soils historically amended with sewage sludge, manure, and compost. J Environ Qual 41:506514. https://doi.org/10.2134/jeq2011.0317

Spurgeon DJ, Hopkin SP (1999) Comparisons of metal accumulation and excretion kinetics in earthworms (Eisenia fetida) exposed to contaminated field and laboratory soils. Appl Soil Ecol 11:227-243. https://doi.org/10.1016/S0929-1393(98)00150-4

Stepanov AM, Tchernenkova TV, Korobov ED (1987) Carabid beetles (Coleoptera, Carabidae) as bioindicators, in: soil fauna and soil fertility. In: Proceedings of IX International Colloquium on Soil Zoology, Moscow, pp 493-494

Talarico F, Brandmayr P, Giulianini PG, Ietto F, Naccarato A, Perrotta E, Tagarelli A, Giglio A (2014) Effects of metal pollution on survival and physiological responses in Carabus (Chaetocarabus) lefebvrei (Coleoptera, Carabidae). Eur J Soil Biol 61:80-89. https://doi.org/ 10.1016/j.ejsobi.2014.02.003

Touceda-González M, Prieto-Fernández A, Renella G, Giognoni L, Sessitsch S, Brader G, Kumpiene J, Dimitriou I, Eriksson J, FrieslHanl W, Galazka R, Janssen J, Mench M, Müller I, Neu S, Puschenreiter M, Siebelec G, Vangronsveld J, Kidd PS (2017) Microbial community structure and activity in trace elementcontaminated soils phytomanaged by Gentle Remediation Options (GRO). Environ Pollut 231:237-251. https://doi.org/10.1016/j. envpol.2017.07.097

Tőzsér D, Magura T, Simon E (2017) Heavy metal uptake by plant parts of willow species: a meta-analysis. J Hazard Mater 336:101-109. https://doi.org/10.1016/j.jhazmat.2017.03.068

Uehara-Prado M, Fernandez JO, Bello AM, Machado G, Santos AJ, Vazde-Mello FZ, Freitas AVL (2009) Selecting terrestrial arthropods as indicators of small-scale disturbance: a first approach in the Brazilian Atlantic Forest. Biol Conserv 142:1220-1228. https:// doi.org/10.1016/j.biocon.2009.01.008

van Straalen NM, van Wensem J (1986) Heavy metal content of forest litter arthropods as related to body-size and trophic level. Environ Pollut A 42:209-221. https://doi.org/10.1016/0143-1471(86) 90032-2

van Straalen NM, Butovsky RO, Pokarzhevskii AD, Zaitsev AS, Verhoef CS (2001) Metal concentrations in soil and in invertebrates in the vicinity of a metallurgical factory near Tula (Russia). Pedobiologia 45:451-466. https://doi.org/10.1078/0031-4056-00099 
Viechtbauer W (2010) Conducting meta-analyses in R with the metafor package. J Stat Softw 36:1-48. https://doi.org/10.18637/jss.v036. i03

Xu L, Lofts S, Lu Y (2016a) Terrestrial ecosystem health under long-term metal inputs: modeling and risk assessment. Ecosyst Health Sustain 2:e01214. https://doi.org/10.1002/ehs2.1214

Xu L, Cao S, Wang J, Lu A (2016b) Which factors determine metal accumulation in agricultural soils in the severely human-coupled ecosystem? Int J Env Res Pub He 13:510. https://doi.org/10.3390/ ijerph13050510

Zhang L, Cornelis AM, van Gestel AM (2017) Toxicokinetics and toxicodynamics of lead in the soil invertebrate Enchytraeus crypticus. Environ Pollut 225:534-541. https://doi.org/10.1016/j. envpol.2017.02.070

Zygmunt PMS, Maryański M, Laskowski R (2006) Body mass and caloric value of the ground beetle (Pterostichus oblongopunctatus) (Coleoptera, Carabidae) along a gradient of heavy metal pollution. Environ Toxicol Chem 25:2709-2714. https://doi.org/10.1897/05580R.1

Publisher's note Springer Nature remains neutral with regard to jurisdictional claims in published maps and institutional affiliations. 